VIVIANE KECHICHIAN

ADIÇÃO DE INGREDIENTES ANTIMICROBIANOS EM FILMES BIODEGRADÁVEIS À BASE DE FÉCULA DE MANDIOCA 


\section{ADIÇÃO DE INGREDIENTES ANTIMICROBIANOS EM FILMES BIODEGRADÁVEIS À BASE DE FÉCULA DE MANDIOCA}

Dissertação apresentada à Escola Politécnica da Universidade de São Paulo para obtenção do Título de Mestre em Engenharia

Área de Concentração:

Engenharia Química

Orientadora: Prof ${ }^{\mathrm{a}}$. Carmen Cecília Tadini

São Paulo 


\section{FICHA CATALOGRÁFICA}

\section{Kechichian, Viviane}

Adição de ingredientes antimicrobianos em filmes biodegradáveis à base de fécula de mandioca / V. Kechichian. -- São Paulo, 2007. $105 \mathrm{p}$.

Dissertação (Mestrado) - Escola Politécnica da Universidade de São Paulo. Departamento de Engenharia Química.

1.Filmes biodegradáveis 2.Fécula de mandioca 3.Panificação 4.Embalagens de alimentos I.Universidade de São Paulo. Escola Politécnica. Departamento de Engenharia Química II.t. 


\section{AGRADECIMENTOS}

Este trabalho foi planejado e realizado com muito cuidado, envolvimento e amor mas, não teria se realizado sem a ajuda de pessoas que contribuíram de forma fundamental para o andamento e o resultado dele.

Agradeço à orientadora Carmen Cecília Tadini pela orientação nos momentos decisivos do trabalho: ela soube aliar conhecimento técnico com agilidade na to mada de decisões e foco em resultados, tão importantes em um trabalho de pesquisa.

Ao grupo de trabalho da professora Mariza Landgraf, do laboratório de Alimentos e Nutrição Experimental da Faculdade de Ciências Farmacêuticas da Universidade de São Paulo, sob a supervisão da Prof ${ }^{a}$. Mariza Landgraf por todo o apoio, paciência e atenção durante o período que realizei as análises microbiológicas que fizeram parte do trabalho.

A todo o pessoal do laboratório de Engenharia de Alimentos da Usp pela amizade, carinho e ajuda nos momentos de dificuldade que eu encontrei. E pelas risadas, conversas animadas que tivemos também.

Em especial agradeço a minha companheira de laboratório e também cunhada Tatiana Beatrís Tribess por ter despertado meu interesse pela área acadêmica e por me ajudar, desde os primeiros dias do mestrado até hoje, a tirar as pedrinhas que têm aparecido no meu caminho.

À minha família maravilhosa: minha mãe Laura, meu pai Antonio, minha irmã Melissa, minha avó Giuliana e meu tio Giuseppe pelo amor verdadeiro, pela torcida e pela confiança que tudo ia dar certo.

Ao meu marido Luiz Roberto, pelo amor e por me estar ao meu lado neste e em todos os meus planos de vida.

À minha filhinha Gabi, que enche minha vida de alegria e que também me ajudou, do seu jeito, a realizar este projeto. 


\section{RESUMO}

Neste trabalho, ingredientes naturais antimicrobianos foram adicionados em filme biodegradável (biofilme) à base de fécula de mandioca tendo como plastificantes sacarose e açúcar invertido. A seleção dos ingredientes antimicrobianos (cravo em pó, canela em pó, pimenta vermelha em pó, óleo essencial de laranja, café em pó, mel e extrato de própolis) foi conduzida por meio de um delineamento experimental (fatorial fracionado $2^{7-3}$ ) e os biofilmes foram analisados quanto às suas propriedades de barreira (permeabilidade ao vapor de água e taxa de permeabilidade ao vapor de água) e propriedades mecânicas (resistência máxima à tração e porcentagem de alongamento na ruptura). Os biofilmes apresentaram valores inferiores aos apresentados pelo biofilme controle quanto às propriedades mecânicas. Em geral, a taxa de permeabilidade ao vapor de água nos biofilmes antimicrobianos manteve-se estatisticamente igual ao do controle. Na segunda etapa do trabalho, a otimização dos ingredientes selecionados foi realizada através de delineamento experimental, com somente adição de cravo e canela em pó, que apresentaram resultados mais promissores na etapa anterior. Foi constatado que a adição de cravo e canela em pó alterou as propriedades mecânicas, porém as alterações foram menos intensas com a adição da canela em pó do que com o cravo em pó, o que pode ser justificado pela diferença de granulometria entre eles. A taxa de permeabilidade diminuiu até certa concentração dos ingredientes $(0,34 \%$ para a canela em pó e $0,20 \%$ para o cravo em pó). $O$ efeito antimicrobiano dos biofilmes foi investigado como embalagem de fatias de pão tipo forma e foi constatado que a atividade de água dos biofilmes aumentou após 7 dias de contato. É provável que os biofilmes tenham se tornado meios propícios para o desenvolvimento de bolores e leveduras visto que estes microrganismos cresceram de forma similar ou mais intensa nas fatias de pão na presença do que na ausência dos biofilmes. A partir dos resultados obtidos, não é possível avaliar de forma clara, o efeito antimicrobiano dos ingredientes incorporados na matriz dos biofilmes contra o crescimento de bolores e leveduras em fatias de pão tipo forma.

Palavras - chave: Biofilmes. Antimicrobianos. Embalagem. Panificação. 


\begin{abstract}
In this work, natural antimicrobial ingredients were added to biodegradable film (biofilm) based on cassava starch with sucrose and inverted sugar as plasticizers. The selection of the antimicrobial ingredients (clove powder, cinnamon powder, red pepper powder, orange essencial oil, coffee powder, honey and propolis extract) was carried out applying an experimental design (incomplete factorial $2^{7-3}$ ) and the barrier properties (water vapour permeability and water vapour permeability rate) and mechanical properties (tensile strength and elongation at break) of the biofilms were determined. The biofilms presented lower data regarding mechanical properties when compared to biofilm control. In general, the water vapour pemeability rate of the antimicrobial biofilms was statistically equal to the control. In the second phase of the work, the optimization of the selected ingredients was carried out applying an experimental design, with the addition of only clove and cinnamon powder due to the fact that they showed the most promissing results at the previous phase. The addition of clove and cinnamon powder modified the mechanical properties but the modifications resulted by the addition of cinnamon powder were less intense than the ones resulted by the addition of clove powder, which can be justified by the particle size differences between them. The water vapour permeability rate decreased by specific ingredients concentration $(0.34 \%$ for the cinnamon in powder and $0.20 \%$ for the clove in powder). The biofilms antimicrobial effect was investigated as packaging of pan bread slices and it was verified that the biofilms water activity increased after 7 days of contact. Probably, the biofilms became suitable substrates for yeast and mold development due to the fact that these microorganisms grew equally or more intensely in the pan bread slices when the biofilms were present in comparison to the cases of its absence. According to the results, it is not possible to evaluate clearly the antimicrobial effect of the added ingredients to the biofilm matrix against yeast and mold development in pan bread slices.
\end{abstract}

Key-words: Biofilms. Antimicrobials. Packaging. Baking. 